Article

\title{
The Evolution of the Kazakhstani Silk Road Section from a Transport into a Logistics Corridor and the Economic Sustainability of Regional Development in Central Asia
}

\author{
Aislu Taisarinova ${ }^{1,2} \oplus$, Giuseppe Loprencipe ${ }^{3, *} \mathbb{C}$ and Madina Junussova ${ }^{4}$ \\ 1 Faculty of Logistics and Management, Kazakh Academy of Transport and Communications, \\ 97 Shevchenko Street, Almaty 050012, Kazakhstan; taisarinova@dku.kz \\ 2 Faculty of Engineering and Information Technology, Kazakh-German University, 111 Pushkin Street, \\ Almaty 050010, Kazakhstan \\ 3 Department of Civil, Constructional and Environmental Engineering, Sapienza University, \\ 18 Via Eudossiana, 00184 Rome, Italy \\ 4 Institute of Public Policy and Administration, University of Central Asia, 138 Toktogul Street, \\ Bishkek 720001, Kyrgyzstan; madina.junussova@ucentralasia.org \\ * Correspondence: giuseppe.loprencipe@uniroma1.it
}

Received: 14 June 2020; Accepted: 3 August 2020; Published: 4 August 2020

check for updates

\begin{abstract}
Central Asian countries attract investment in transport infrastructure to rebuild the Silk Road paths and enjoy economic benefits from the participation in international trade. The Kazakhstani government approached the Russian and Chinese governments intending to join the Western Europe-Western China (WE-WC) initiative to boost the country's regional development. The paper aims to assess how the WE-WC transport corridor affected the economic potential of linking cities and regions starting from the quality of transport infrastructure and leading to their export potential. The study's findings showed that the Kazakhstan section of the WE-WC corridor was at an early stage of transformation from a transport into an economic corridor. While the Russia-Uzbekistan section continues to serve mainly a transit function and operate at the level of transport infrastructure, the China-Kyrgyzstan section has started evolving from the level of multimode transport corridor to the level of logistics corridor. The economic sustainability of the WE-WC linking mining and agricultural regions of Kazakhstan still comes into question and depends on the government's further region-specific policy actions.
\end{abstract}

Keywords: The Silk Road in Central Asia; Western Europe-Western China (WE-WC); international trade; transport corridor; economic corridor; sustainable regional development; economic complexity; regional capability

\section{Introduction}

Since the collapse of the Soviet Union, landlocked independent Central Asian countries have been trying to attract investment through the development of transport corridors and propose new versions of the modern Silk Road routes to reconnect Europe and Asia. Since 2001, 11 countries including Kazakhstan, Kyrgyzstan, Tajikistan, Turkmenistan, and Uzbekistan have been collaborating in the framework of the Central Asia Regional Economic Cooperation (CAREC) partnership program. The program allowed them to mobilize more than US \$37 billion in investments by 2019, mainly aimed at the development of railway infrastructure [1]. Among the Central Asian countries, Kazakhstan was the first country that proposed a new Silk Road initiative in 2007 to Russia and China under the 
umbrella of the Western Europe-Western China project (WE-WC) [2]. The WE-WC transport corridor aimed to decrease the shipping time for the delivery of goods from China to Europe and back from 30-50 days by sea and 12-15 days by railway to 7-10 days along the highway [3].

For participating countries such as Kazakhstan, Russia, and China, the implementation of the WC-WE project was expected to bring additional economic benefits such as (i) increased quality of road infrastructure; (ii) a reduced number of road accidents; (iii) higher volumes of trade; and (iv) better regional development resulting from the participation of linking cities and regions in international goods exchanges. In the case of Kazakhstan, in addition to the strengthening of the country's transit potential, the WE-WC transport corridor aimed to boost regional development and benefit at least $30 \%$ of the country's population, including 5.5 million people living in 200 settlements located along the corridor [2]. The WE-WC project, initiated by the government of Kazakhstan before the Chinese Belt and Road Initiative (BRI), serves as an insightful case to study the impact of foreign investment in the Silk Road transport corridor on the sustainability of regional development in Central Asia. The Chinese government's announcement, in 2013, of its new vision of the Silk Road, named the Belt and Road Initiative (BRI), was, to a certain extent, stimulated by the established institutional setting of the Eurasian Economic Union [4] and the benefits expected from the implementation of the WE-WC project [5]. While the WE-WC project was financed by many international banks, BRI had a single investor. The Chinese government allocated US $\$ 1$ trillion to the development of infrastructure with a special focus on Central Asian countries, whose territories can serve as land bridges for connecting China with Europe [6].

The growing investment interests of China and other development institutions gave a certain impetus to the academic discussion about the importance of scientific evidence to understand the impact of the investments in the construction of transport infrastructure on the future economic development of the respective countries [5,7]. Particularly, scholars raise awareness about the danger of the political dependence of Central Asian countries on China, if they cannot pay back the received loans [8-11]. Most scholars focus on the political [12,13], social [14], and environmental impacts [15-17], whereas only few scholars analyze the economic impact of the BRI-associated transport projects on the sustainability of regional development $[2,18]$. In many transport studies, sustainability is often associated with a negative environmental impact, while other studies focus on the improvement of the environmental standards $[19,20]$. Unlike the dominating sector-specific views on transport sustainability, the authors propose to assess sustainability by applying an integrated approach. The proposed integrated approach aims to achieve an adequate synergy between the social, environmental, and economic dimensions that lie at the core of the sustainability concept [21].

The authors suggest assessing the impact of the investment on the sustainability of transport and sustainable regional development by considering the existing interdependence between transport, trade, economic development, and environment. To achieve conceptual clarity, the authors interpret sustainable transport as a catalyst for a sustainable economy. The sustainable transport corridor aims to improve the efficiency of trade flow and serves as a key impetus for the development of new logistics chains. Sustainable transport results in sustainable trade that stimulates local companies to explore global markets and increase the competitiveness of locally produced goods. Together, sustainable transport and trade pave the way for sustainable logistics and economic development by boosting an innovative business environment. Sustainable transport, trade, and logistics enable and motivate local companies to produce globally demanded environmentally friendly products, ultimately decreasing the dependence of the regional economy on mining and export of commodity goods.

In the case of Central Asian countries, there is a high interdependence between environmental and economic sustainability. For example, sustainable development in Kazakhstan directly depends on the country's efforts to switch from a natural resource-based economy to a more diversified service-based economy. There is a great hope that transport infrastructure will play the role of the main catalyst for this transition to sustainable economic development. However, to the authors' best knowledge, 
there is a shortage of studies analyzing how in-country economic development is affected by transport corridors in Central Asia. It is still unclear how the received external investment in the large-scale transport infrastructure projects will affect the economic sustainability of Central Asian cities and regions. Central Asian governments constantly aim to rebuild the Silk Road transport infrastructure by designing new transport routes, such as the WE-WC project, or by joining Chinese BRI-related initiatives. However, the Central Asian governments' actions are taking place in the absence of evidence about the real impact of the attracted investment in the construction of transport infrastructure on regional development in the Central Asian context [22].

The paper aims to fill this gap and assess the impact of the externally funded WE-WC project on the development of the linking regions and cities of Kazakhstan. The study findings showed that the WE-WC corridor was more beneficial to agricultural regions located close to large cities neighboring China and Kyrgyzstan rather than to mining regions neighboring Russia and Uzbekistan. However, the economic sustainability of the WE-WC linking regions still comes into question due to the poor quality of the road and the lack of regional support. If Central Asian governments want to benefit from Silk Road projects in the long run, the investment in the construction or rehabilitation of roads should be complemented by additional funding on the regional level to assure a high level of road maintenance and adequate development of the road safety equipment. It is crucial to engage regional governments and key economic players in the discussion on how they can benefit from the use of the WE-WC corridor.

\section{Research Methodology}

Well-developed transport corridors are recognized as one of the key prerequisites for the sustainable development of trade and economic diversification because they facilitate interregional human and goods mobility $[23,24]$. Not surprisingly, overtime transport corridors became a policy tool aiming to enable regional development [25], particularly in so-called developing countries and countries in transition [5]. International development banks and aid organizations actively promote the idea that transport corridors can boost regional development by attracting foreign investment and a better transport of goods from regions of production to target local and international markets [5]. Investors like China provide aid and loans to Central Asian countries including Kazakhstan for the development of transport infrastructure, driven not only by the interest in connecting to Europe, but also by prospects of tapping into the energy resources of these countries to feed their growing economies $[11,26]$. At the same time, as practical cases show, the countries receiving investment for the construction of transport infrastructure can only obtain economic benefits if there are adequate conditions for the evolution of the transport corridor. More specifically, the transport corridor should develop from a physical infrastructure to an economic corridor $[27,28]$ with multimodal transport links and logistic services [29].

In this paper, the authors applied the theory of change [30] that had been adopted by international banks to conduct a comprehensive evaluation of the impact of investment on development. Based on the analysis of the role of transport corridors in regional development $[31,32]$ and applying the theory of change, we developed a methodological framework for an integrated assessment of the WE-WC corridor's impact on regional development (see Figure 1). International literature suggests that transport corridors play an important role in the facilitation of regional development. However, scholars recommend distinguishing between differing impacts of transport corridors on regional development depending on the stage of development [33]. The methodological framework (see Figure 1) allowed us to make a step-by-step comprehensive assessment of the evolution of the transport corridor. The impact of the transport corridor on regional development directly depends on the stage of corridor development.

There are four main stages of corridor development to be considered while developing impact pathways and related assumptions. During the first stage of corridor development, called "transport infrastructure" (see Figure 1), the impact can be only assessed with regard to transport infrastructure. 
The construction or rehabilitation of the road leads to an improved physical connection between regions. Better road connections and high-quality roads result in increase in the volume of transported goods [18]. During the second stage of corridor development, named "multimode transport corridor", the improved connection creates better conditions for trading. When the transport corridor transforms into a multimode transport corridor, creating an adequate level of integration of different forms of transport, it starts to stimulate trade and allows regions to benefit from improved access to international markets [29]. During the third stage of corridor development, named "logistics corridor", the regions start to receive greater benefits in the form of new goods and services. The regional economy diversifies because the transport corridor, together with a favorable business climate, stimulates the development of processing industries, logistics, and other services [18]. During the last stage, when a transport corridor develops into "an economic corridor", the corridor starts promoting the sustainable economic development of linking regions by impacting economic diversification and stimulating the production of innovative goods and services that increase regional competitive advantage [34].

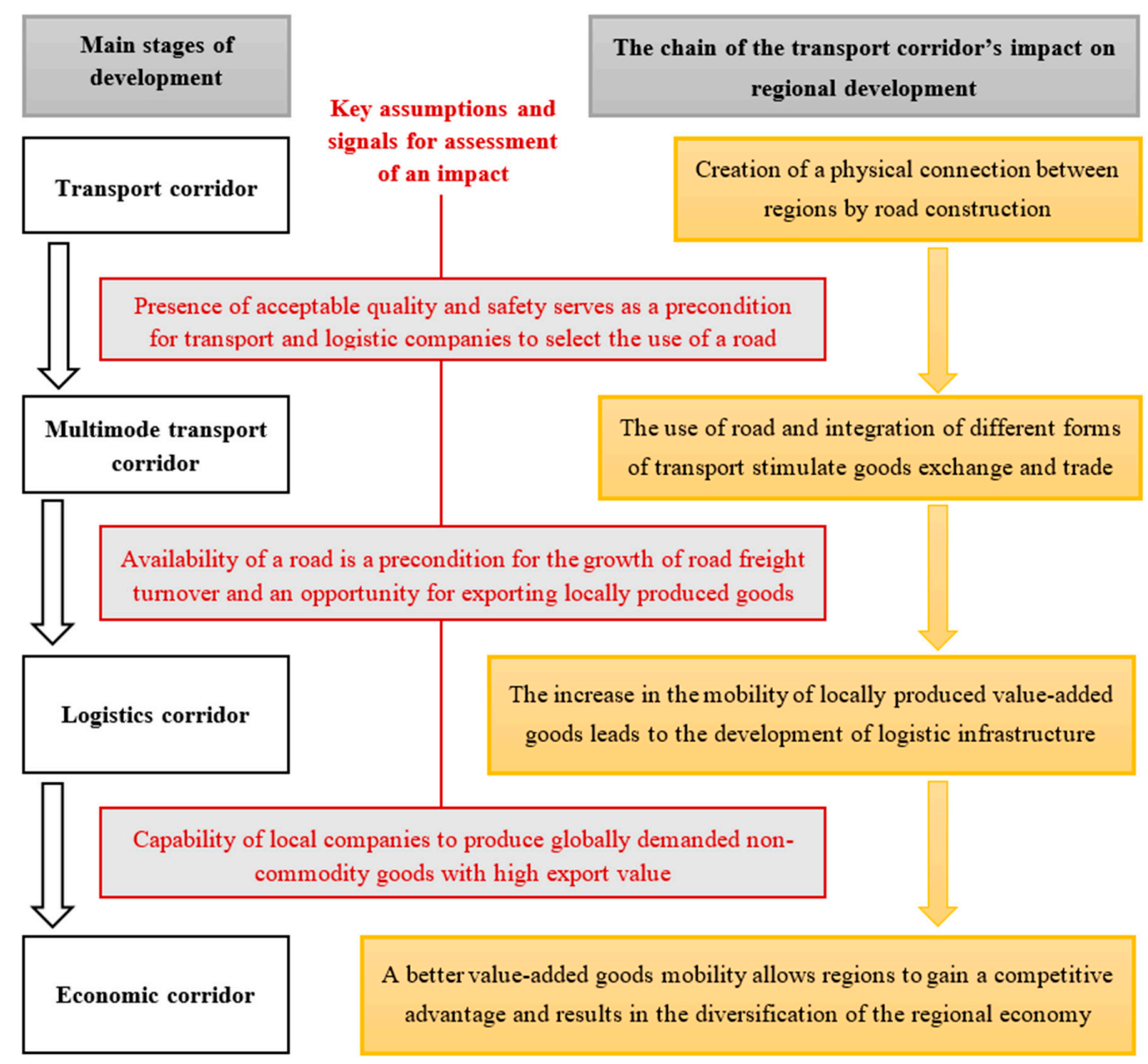

Figure 1. The methodological framework for the assessment of impacts of the Western Europe-Western China (WE-WC) transport corridor on regional development (developed by the authors based on [18,31]).

One of the WE-WC road project's objectives was to improve the quality of transport connections to increase road safety and decrease maintenance costs. Therefore, the study starts with the analysis of the change in transport connection by focusing on road quality and safety. The better transport connection along the WE-WC transport corridor was assumed to increase the volume of goods transported through the country and positively influence the export potential of the linking regions. Therefore, the assessment of road quality is followed by the analysis of the change in cargo turnover and export 
structure. Lastly, the analysis of trade structure is further complemented by the assessment of the regional capabilities to produce non-commodity goods with high export value.

The data sources include regional statistics retrieved from the official website of the State Revenue Committee of the Ministry of Finance of the Republic of Kazakhstan [35], the State Committee on Statistics of the Ministry of National Economy [36], and data on trade from the World Bank [37]. While collecting data on Kazakhstan's regions, the authors faced considerable obstacles. It was challenging to find regional transport data from different historical periods that were statistically developed using the same methodology and could be compared. Due to the lack of reliable data, the authors could not use the initially planned variables and could not determine all feasible empirical correlations that had been planned. As a result, the authors adopted a limited number of indicators. The authors selected only historically stable indicators (created using the same methodology) that allowed to track the progress or compare the change before and after the WE-WC project. In addition to annually collected regional statistics, the authors used the findings of the field study of the Transport and Communications Research Institute (NIITK) [38], the road safety results of the Center for Strategic and International Studies (CSIS) [39], and the findings of the study by Whiteshield Partners on the economic complexity of regions in Kazakhstan [40].

The capability-based approach used by Whiteshield Partners allowed the authors to assess the development potential of the WE-WC linking regions (2003-2014) [40]. The Whiteshield Partners adopted the Economic Complexity concept developed by Hausmann and Hidalgo to assess the change of regional capabilities in Kazakhstan for ten years (2003-2014) [40]. The concept of Economic Complexity was proposed to measure the level of accumulated productive knowledge [41]. It assumes that if a country produces a certain type of products, it has all the required capabilities for supporting the production process of these products [42]. The country's capabilities include the availability of favorable economic and regulatory conditions, adequate development of the business environment, as well as physical and human capital. With the growth of countries' capabilities, they produce more complex products, and their economy becomes more diversified.

The Country Capability Index was adjusted by Whiteshield Partners to identify the regional capabilities of Kazakhstani regions by measuring the Regional Capability Index (RCI). The RCI represents a combination of four key indicators: Revealed Comparative Advantage (RCA), Regional Economic Complexity Index (RECI), Contribution to Services Sector Index (CS), and Processing Sector Index (PC). The RCA measures the level of economic diversification of a region, by reflecting the diversity of export products from that region. The RECI reflects the export potential of a region, showing the multiplicity of the available productive knowledge. The CS represents the complexity for services accompanying the production of exported products, calculated as a ratio of the share of services in the gross regional product (GRP) of a region to an average share of services in national GRP. The PC represents the level of processing sector development and is calculated as a ratio of the share of processing industries in the GRP of a region to an average share of processing industries in the national GRP.

\section{Impact of the WE-WC Transport Corridor}

\subsection{WE-WC Project}

This section aims to provide background information about the WE-WC project. The first President of Kazakhstan, Nursultan Nazarbayev, officially announced the WE-WC project in 2008, during his annual address to the people of Kazakhstan [43]. In 2008 and 2009, the government of Kazakhstan signed a memorandum on the WE-WC corridor development with Russia and China [44]. By initiating the WE-WC project, Kazakhstan wanted to facilitate the Eurasian integration by linking the major players: China and Russia. Historically, Kazakhstan has already been connected to Russia, and these two countries, together with Belarus, established the foundations of the Eurasian Economic Union [4], whereas the successful cooperation between Kazakhstan, Russia, and China started to 
develop after the creation of the Shanghai Cooperation Organization [45]. In 2016, the governments of Kazakhstan and China signed a cooperation plan aimed to link the two countries' infrastructure projects, namely Nurly Jol and Silk Road Economic Belt [46].

The WE-WC transport corridor is a continental alternative of the Trans-Siberian Railway and the maritime traffic through the Suez Canal. The WE-WC route was assumed to decrease the time of transport from 45 days required for sea freight shipping and 14 days for freight transport along the Trans-Siberian Railway to 10 days (see Figure 2). The total length of the WE-WC transport corridor is $8445 \mathrm{~km}$ : $2233 \mathrm{~km}$ of which run through the territory of Russia, $2787 \mathrm{~km}$ through Kazakhstan, and $3425 \mathrm{~km}$ through China [3].

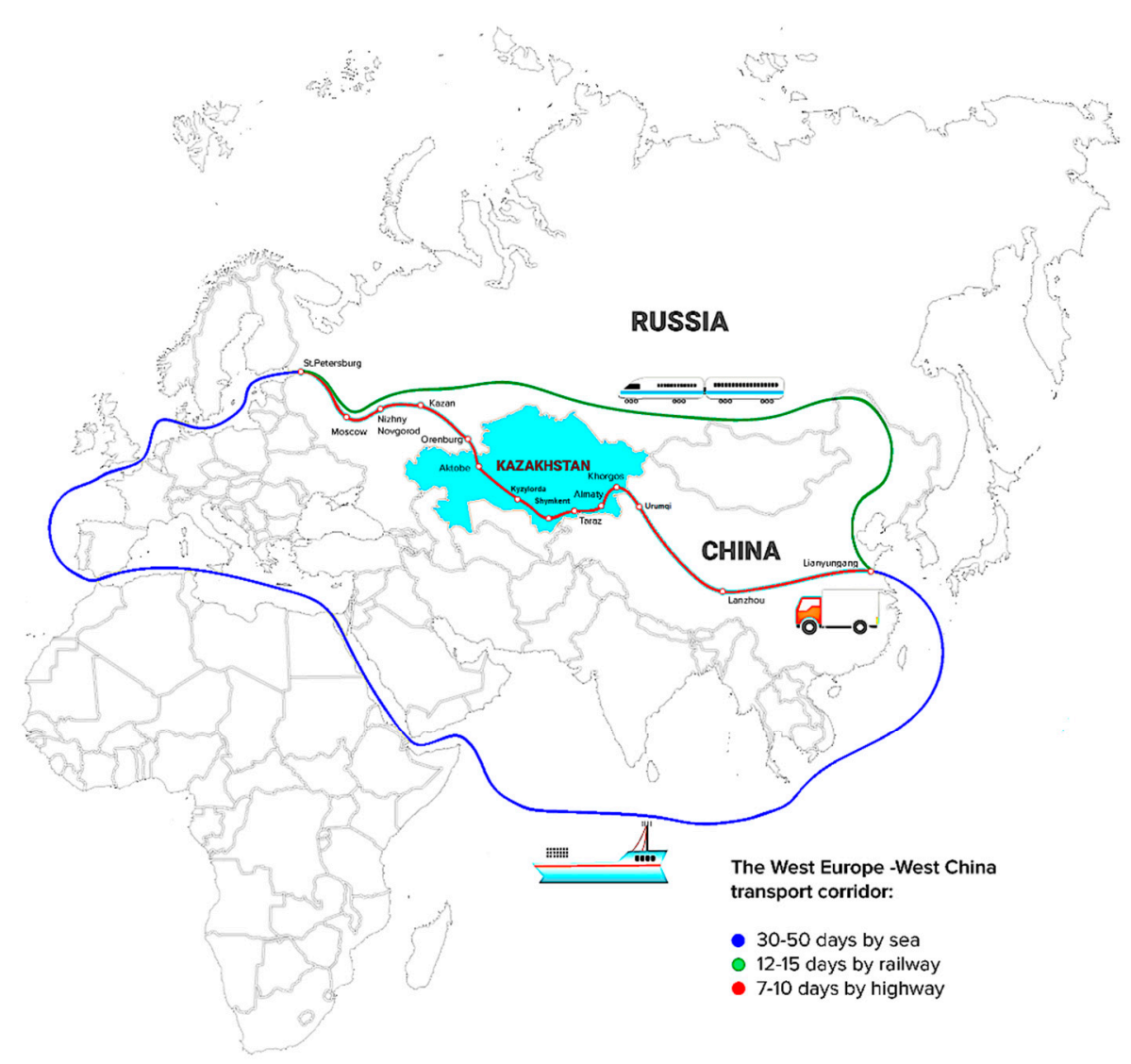

Figure 2. Western Europe-Western China international transit corridor (developed by the authors based on [3]).

The Chinese government was the first one to announce the completion of its section ( $3425 \mathrm{~km})$ of the WE-WC transport corridor in 2017, at the opening ceremony of the high-speed motorway G218 starting in Khorgas city, the Xinjiang Uyghur Autonomous Region. In the case of the Chinese section of the WE-WE corridor, the Chinese government covered all project-related expenses using the state budget [47]. The Chinese section of the WE-WC corridor passes through the Chinese cities of Khorgas, Urumchi, Lanzhou, Zhengzhou, and Lianyungang.

The Russian section is under construction, and the Russian government has included the implementation of the WE-WC in the national infrastructure plans to be completed by $2024[48,49]$. The Russian government covered only $60 \%$ of the WE-WC project cost (or US $\$ 6$ billion out of US $\$ 10$ billion) using the state budget [47,49]. The Russian section of the WE-WC corridor links the Russian cities of Saint Petersburg, Moscow, Nizhny Novgorod, Kazan, and Orenburg. As suggested by scholars, there is a shorter alternative route that goes from Moscow to Berlin via Minsk and Warsaw [4]. However, the Russian government proposed the route passing through Saint Petersburg to allow the northwestern regions to benefit from the WE-WC corridor. 
The Kazakhstan section of the WE-WC transport corridor, from Khorgos (East Kazakhstani-Chinese border) to the border point of Zhaisan (Russian-North West Kazakhstani border), entailed the rehabilitation of $2452 \mathrm{~km}$ of the road [50]. According to the project, the Kazakhstani section of the WE-WC corridor passes through the territory of the Aktobe $(590.64 \mathrm{~km})$, Kyzylorda $(810 \mathrm{~km})$, Turkestan $(294 \mathrm{~km})$, Jambyl $(427 \mathrm{~km})$, and Almaty regions $(460 \mathrm{~km}$ ) of Kazakhstan, and the cities of Almaty and Shymkent, that are regionally important [51]. The mining industry is the main economic sector of the Aktobe, Kyzylorda, and Turkestan regions and Shymkent city. However, as in the case of the Aktobe region, most of the commodity goods (oil, chromium, copper, zinc, and ferrous metals) are exported by railways [52-56]. The minerals exported from Kyzylorda include oil, zinc, lead, uranium, gold, and silver. The key export goods of Turkestan and Shymkent are aluminum, copper, and black metals [52,53]. The Jambyl and Almaty regions are agricultural. The government selected Almaty, Aktobe, and Shymkent as key destinations for the public investment in logistics infrastructure, so as to become multimode transport hubs supporting the further development of the WE-WC corridor [57]. In 2008, the Damu Logistics Center, with the capacity to serve a freight turnover of 10 million tons per year, was commissioned in Almaty [58]. In 2016, the Logistics Center, with the capacity to serve a freight turnover of 1 million tons per year, was established in Aktobe [57]. In 2019, the Continental Logistics, with the capacity to serve a freight turnover of up to 600,000 tons of cargo per year, started to operate in Shymkent [57].

The government of Kazakhstan covered $21 \%$ of the total project cost of the WC-WE project, that equaled to US $\$ 3.4$ billion, using the state budget, while the rest of the money was borrowed for 25 years from several international development banks (see Table 1). The World Bank, experiencing the increasing financial and administrative pressure from China, contributed the largest share of loans by investing US $\$ 2.1$ billion. The Kazakhstani government plans to complete the implementation of the WE-WC road rehabilitation by the end of 2020 [59]. The government of Kazakhstan expected that the commissioning of the WE-WC would lead to the growth of the road freight turnover and that the average annual savings associated with the reduction of travel time within the country would amount to US \$280.2 million [2]. The road freight transport plays an important role in goods exchange. In 2017, the road freight transport of Kazakhstan served $82.4 \%$ of the total volume of non-commodity goods [52,53]. Moreover, by implementing the WE-WC project, the government of Kazakhstan aimed to save US $\$ 75$ million from improved road safety [3]. According to the CSIS estimates, road crashes cost on average $4 \%$ of the Kazakhstan GDP, or US $\$ 9$ billion [39].

Table 1. Investments in the WE-WC section of Kazakhstan (developed by the authors based on [3]).

\begin{tabular}{lc}
\hline \multicolumn{1}{c}{ Investing Institution } & Volume of Investment \\
\hline The government of the Republic of Kazakhstan & US $\$ 0.9$ billion \\
Loans from several international development banks, including: & US \$3.4 billion \\
International Bank for Reconstruction and Development (World Bank) & US $\$ 2.1$ billion \\
Asian Development Bank & US $\$ 0.7$ billion \\
Islamic Development Bank & US $\$ 0.4$ billion \\
European Bank for Reconstruction and Development & US $\$ 0.2$ billion \\
\hline
\end{tabular}

In addition to the implementation of the WE-WC project, since 2003, the government of Kazakhstan has adopted several policy documents to improve the business environment, to diversify the national economy, and to increase the non-commodity value of the export potential of the country. In 2013, the government introduced the national program for the Development and Support of Small Business 2004-2006 [60]. In 2010, the government started to run the national program the Road Map of Business 2020 [61]. In 2003, the government adopted the Strategy of Industrial and Innovative Development 2015, and in 2010 the national program of Fast Industrial and Innovative Development 2010-2014, to push the local industries to produce more non-commodity, value-added products [62]. The country Transport Strategy 2015 was introduced in 2006 to increase the share of non-commodity goods exported from Kazakhstan [63]. Finally, in 2017, the government enacted the National Export Strategy of Kazakhstan 
2018-2022, that aimed to double the volume of non-commodity exports [64]. However, there is poor implementation of enacted policies on the regional level [65]. The regional governments lack the capacity to allow local producers to benefit from the nationally established institutional conditions.

\subsection{The Change of Quality of Transport Infrastructure}

This section aims to assess the change in road quality and safety along the WE-WC transport corridor. The study's findings showed that the quality of the road along the WE-WC corridor had already been impacted at the investment and construction stages. Investing banks divided the WE-WC road into several sections with different lengths (see Table 2). Every bank selected a road section they wanted to finance and supervised the road rehabilitation from the design to the implementation stage according to their internal policies [3]. Different construction companies, selected by the public tender, built the WE-WC road sections during different periods (see Table 2), and this patchwork approach to the construction of the WE-WC road negatively impacted the road quality.

Table 2. The WE-WC project implementation periods, length, and road surface by sections (developed by the authors based on $[3,66])$.

\begin{tabular}{|c|c|c|c|c|}
\hline Regions & Route Section Name & Period of Time & Length, km & Road Quality Reported by Users \\
\hline \multirow{4}{*}{ Aktobe region } & Aktobe-Karabutak-Irgiz & $2003-2006$ & 273 & III \\
\hline & $\begin{array}{l}\text { Karabutak-border of } \\
\text { Kyzylorda region }\end{array}$ & 2009-2012 & 215 & I \\
\hline & Martuk-Aktobe & $2012-2015$ & 102 & I \\
\hline & $\begin{array}{c}\text { Northern bypass of the } \\
\text { Aktobe city }\end{array}$ & 2013 & 39.4 & II \\
\hline \multirow{4}{*}{ Kyzylorda region } & border of Aktobe-Zhalagash & \multirow{4}{*}{$2012-2015$} & 555 & II \\
\hline & Zhalagash-Enbek & & 22 & III \\
\hline & Enbek-Kyzylorda & & 72 & II \\
\hline & Kyzylorda-Shymkent & & 456 & II \\
\hline $\begin{array}{l}\text { Turkestan region } \\
\text { and Shymkent city }\end{array}$ & $\begin{array}{c}\text { Tashkent-Shymkent-border } \\
\text { of Zhambyl region }\end{array}$ & $2012-2015$ & 203 & I \\
\hline \multirow{2}{*}{ Jambyl region } & $\begin{array}{l}\text { border of Turkestan region } \\
\text { Taraz-Khorday }\end{array}$ & 2009-2012 & 480 & II \\
\hline & $\begin{array}{c}\text { Almaty-Tashkent-Termes } \\
\text { bypass Khorday }\end{array}$ & 2018 & 40 & I \\
\hline \multirow{2}{*}{$\begin{array}{l}\text { Almaty region and } \\
\text { Almaty city }\end{array}$} & \multirow{2}{*}{ Almaty-Bishkek } & \multirow{2}{*}{ 2015-2018 } & 51 & I \\
\hline & & & 154 & II \\
\hline Almaty region & Almaty-Khorgos & 2012-2016 & 301 & I \\
\hline
\end{tabular}

The assessment of the road quality along the WE-WC corridor showed that the road rehabilitation and construction works did not help to obtain the planned high-quality road, satisfying the internationally accepted technical category I for highways. Moreover, the road quality is not the same, differing from section to section (see Table 2). According to the 2016 survey on the users' perceptions, only $30 \%$ of the road along the WE-WC corridor met the requirements of the technical category I (high-speed motorways with a dividing strip, speed $120 \mathrm{~km} / \mathrm{h}$ ), $60 \%$ of roads fell under the technical category II (excellent asphalt/concrete for 5 points, speed $100 \mathrm{~km} / \mathrm{h}$ ); and $10 \%$ were roads corresponding to the technical category III (medium asphalt by 3 points with patches, waves, small rut, speed $60-80 \mathrm{~km} / \mathrm{h}$ ) (see Table 2). According to the NIITK field study, in 2018, even recently commissioned road sections required additional repair and renovation because of road distresses such as cracks and potholes [38]. The unsatisfactory quality of even newly commissioned road sections along the WE-WC corridor could be explained by the poorly managed maintenance of roads and the underdevelopment of road safety infrastructure. The road maintenance in Kazakhstan is managed by the regions, and the capacity of regional representatives to maintain the roads differs from region to 
region [65]. The road maintenance at the regional level directly impacts road quality, as well as the traffic safety [50].

The assessment of the road quality along the WE-WC by regions showed that the poor quality of roads resulted in a different volume of traffic flow in different regions (see Figure 3). The comparison of the NIITK data on traffic flow [38] with the CSIS data on the road quality [39] by regions revealed how road quality was related to traffic flow by regions. In the Aktobe region, only $61.6 \%$ of roads were in good condition, and there was the lowest traffic flow, of 2000 cars per day. In the Kyzylorda region, $73.6 \%$ of roads were in good condition, and the traffic flow was 5000 cars per day. In the Jambyl region, $69 \%$ of roads were in good condition, and the traffic flow was 6000 cars per day. The highest share of roads in good condition (more than $80 \%$ ) was observed in the Turkestan and the Almaty regions, as well as the highest traffic flow, of over 7000 cars per day (see Figure 3). However, it is worth mentioning that the highest traffic flow in the Turkestan and the Almaty regions could be caused not only by the high quality of the road, but also by these regions' locational advantage, neighboring the large cities of Almaty and Shymkent. Almaty and Shymkent also serve as the country's major multitransport hubs, bordering with China and Uzbekistan.

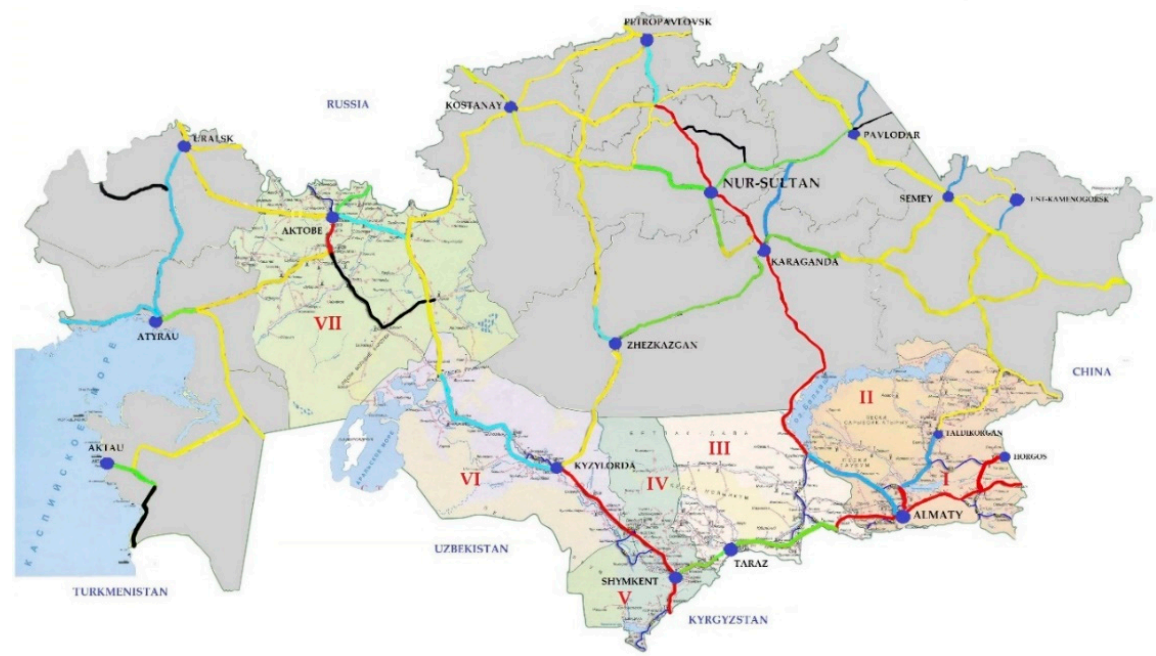

\begin{tabular}{llll}
\hline \multicolumn{2}{l}{ Car intensity per day } & from 3000 to 5000 \\
\hline & Over than 7000 & from 1000 to 3000 \\
\hline & from 5000 to 7000 & less than 100 \\
\hline \multicolumn{2}{l}{ Digital index of the region (city) } & IV & Turkestan region \\
\hline I & Almaty city & V & Shymkent city \\
\hline II & Almaty region & VI & Kyzylorda region \\
\hline III & Jambyl region & VII & Aktobe region \\
\hline
\end{tabular}

Figure 3. The traffic intensity by roads of Kazakhstan in 2018 (developed by the authors based on [38]).

The evaluation of the WE-WC corridor impact allowed for the identification of the evolved interdependence between road quality, transport speed, and safety. The road users changed their behavior on the roads with poor pavement as they wanted to avoid possible financial and safety risks. The NIITK study showed that the low quality of roads and the lack of adequately installed road safety equipment resulted in a decrease in the transport speed in some road sections [38]. The allowed speed for the highways in Kazakhstan is up to $120 \mathrm{~km} / \mathrm{h}$. However, drivers using the WE-WC route prefer not to exceed the speed of $80 \mathrm{~km} / \mathrm{h}$ to avoid possible vehicle damage or road accidents. The poor pavement impacted safety because a poor road surface started to lead to a higher variation of speed, increasing the likelihood of road accidents [39]. In 2018, from $60 \%$ to $80 \%$ of accidents in the WE-WC transport corridor linking regions were associated with low-quality roads [50,67]. 
Despite the poor quality of roads identified earlier, there was the growth of the road freight turnover in the WE-WC regions. The road freight turnover in the WE-WC regions increased 2.4 times from 29,477 million ton-kilometers in 2009 to 71,579 million ton-kilometers in 2018 [68]. The financial value of the goods turnover in the WE-WC regions increased 1.6 times from US $\$ 17,405$ million in 2010 to US $\$ 27,149$ million in 2018 [68]. The total income of Kazakhstani companies serving the road transport of goods increased 3.3 times from KZT 36 billion (US \$299 million) in 2008 to KZT 120 billion (US $\$ 368$ million) in 2017 [68]. The observed positive change allows us to assume that the country can gain even a higher increase in the road freight turnover if the road quality and safety are improved. For example, better-quality roads can attract more foreign companies to the Kazakhstani market. Nowadays, there is a low share of foreign companies serving the road freight turnover in Kazakhstan [68]. For the foreign transport companies, the use of the poor-quality road is an unacceptably risky business.

The transport corridor develops into the multimode corridor when the road is of acceptable quality and safe. The quality of road infrastructure directly affects the transport speed, traffic flow, as well as road freight turnover. In the trade logistics, safety plays a key role in the selection of the best route for transport companies [69]. For example, only some types of cargo that generally do not require special transport conditions can be transported along the roads with a poor quality of road surface. For the transport of special cargo (valuable, heavy, dangerous, etc.) it is critical to have a high-quality road surface. The use of roads with poor quality leads to the rapid deterioration of vehicles that transport goods and increases the chances of road accidents. The government of Kazakhstan expected that the annual maintenance expenses would decrease by US $\$ 72.5$ million after the rehabilitation of the highway [2]. This assumption related to the maintenance savings was initially mistaken. If the government wants the WE-WC corridor to be selected by road users for the transport of goods, there is an urgent need to complement the construction of new roads with adequate investment. Regions of Kazakhstan need additional funding for better management of road maintenance and the development of road safety equipment.

The analysis of the road quality and safety revealed that the WE-WC project did not bring the expected improved physical connection between regions. The Kazakhstani section of the WE-WC failed to create decent transport conditions for road users and provide the assumed shorter route to save the traveling time. The roads' poor quality and unsafe conditions call into question the future role of the Kazakhstani section of the WE-WC road in the stimulation of international trade. There is a hope that the recent government's actions, such as the introduction of road quality control compliance with the European standards started in 2020 [70], may help to guarantee sustainable mobility along the Kazakhstani section of the WE-WC corridor. However, the success of the new road quality control may continue to be dependent on the level of engagement of regional players in the implementation process.

\subsection{The Change of Trade, Export Value, and Trade Serving Infrastructure}

This section aims to assess the change in trade and export potential of regions along the WE-WC transport corridor. Before sharing the evaluation results, it is worth mentioning that the government of Kazakhstan started to implement the WE-WC project close to 2008, when international trade, affected by the global financial and economic crisis, began experiencing a considerable decline. The great recession highly affected the participation of Kazakhstan in international trade because commodities remained the main trading goods exported from Kazakhstan to Europe and China. For example, in 2019, Kazakhstan exported $69.4 \%$ of all exported gas to China and $29.4 \%$ of the exported oil to Italy [53,54]. After the great recession in 2009, the international trade growth slowed down, as well as the economic development of many countries and regions. Compared with the pre-crisis average of 7.1\% (1987-2007), in 2012 and 2013 international trade's growth rate did not exceed 3\% [55]. Considering the negative impact of the global crisis on trade, the further analysis of the change of trade starts with the analysis of the trade between countries that are potential users of the Kazakhstani section of the WE-WC corridor. 
The analysis of the trade between countries linked by the WE-WC corridor showed that there was a higher growth of trade between China, Russia, and Central Asian countries. During 2009-2018, the value of exports from China to Europe, as well as the value of imports from Europe to China, increased only 1.8 times [54,55]. A similar low increase of export and import values was observed between Russia, Kyrgyzstan, and Uzbekistan [55]. Compared to the trade development between China and Europe, the trade development between China and Russia showed better results. During 2009-2018, the value of export from China to Russia increased 3.1 times, and the export from Russia to China 2.8 times [71]. Moreover, the trade between China and Central Asian countries has also grown. The value of goods imported from Kyrgyzstan to China increased 6 times from US \$0.4 million in 2009 to US $\$ 2.3$ million in 2018 [71]. The value of exports from China to Kyrgyzstan increased 2.1 times from US $\$ 183$ million in 2009 to US $\$ 282$ million in 2018 [71]. The value of exports from China to Uzbekistan increased 3 times from US \$621 million in 2009 to US \$1899 million in 2018 [71]. The value of exports from China to Kazakhstan increased 2.4 times from US \$1327 million in 2009 to US \$3169 million in 2018 [71]. The positive trade trends between China and Russia, as well as the Central Asian countries, are a good prerequisite for the future success of the WE-WC corridor and its linking regions.

The analysis of the export potential of the WE-WC linking regions allows us to conclude that the mining regions located at the Russia-Uzbekistan section of the WE-WC corridor could not overcome the dependence on the export of commodity goods. Aktobe, Kyzylorda, Turkestan, and Shymkent continue to experience the highest dependence on the export of natural resources. Consequently, their economy remains unsustainable and vulnerable to a financial crisis on the global market. Compared to 2010, the highest decrease in the goods turnover among the WE-WC regions in 2018 was observed in the Kyzylorda region (4.7 times), followed by the Aktobe region (1.9 times) (see Table 3). During 2010-2018, the financial value of exports in the WE-WC regions decreased 2 times from US $\$ 17,346$ million in 2010 to US $\$ 8371$ million in 2018, while the highest decrease in exports was observed in the Kyzylorda region (5.7 times), followed by the Aktobe region (2.1 times) (see Table 3).

Table 3. Goods turnover and export value by WE-WC regions in 2010 and 2018 in US \$ million (based on [53]).

\begin{tabular}{ccccc}
\hline \multirow{2}{*}{ WE-WC Regions } & \multicolumn{2}{c}{$\mathbf{2 0 1 0}$} & \multicolumn{2}{c}{$\mathbf{2 0 1 8}$} \\
\cline { 2 - 5 } & Goods Turnover & Export & Goods Turnover & Export \\
\hline Almaty region & 1410.1 & 192.5 & 1962.9 & 385.5 \\
Jambyl region & 572.5 & 274.2 & 636.3 & 294.9 \\
Almaty city & $17,320.8$ & 4935.3 & $16,295.1$ & 3347.4 \\
Turkestan region and Shymkent city & 3121.1 & 1192.9 & 3136.8 & 1506.9 \\
Aktobe region & 8063.5 & 6199.6 & 4208.8 & 2957.2 \\
Kyzylorda region & 4237.6 & 3816.1 & 909.2 & 666.8 \\
Total: WE-WC regions & $17,404.8$ & $17,345.9$ & $27,149.1$ & 8370.5 \\
\hline
\end{tabular}

Agricultural regions located along the WE-WC corridor, forming the China-Kyrgyzstan section, showed better performance when it comes to the increase of the share of exported non-commodity goods. However, some of these regions still have a low number of companies serving the road freight transport. Compared to 2010, in 2018, among the WE-WC regions, the highest increase in goods turnover was in the Almaty region (1.4 times) and the Jambyl region (1.1 times), located at the China-Kyrgyzstan section of the WE-WC corridor (see Table 3). The highest increase in export took place in the Almaty region (2 times) and the Jambyl region (1.1 times) (see Table 3$)$. The Jambyl and Almaty regions were also leading in the share of exported non-commodity goods. In 2018, non-commodity goods constituted $93 \%$ of the export goods from the Jambyl region and $88 \%$ of the export goods from the Almaty region (see Figure 4). At the same time, the Jambyl and Almaty regions remain underdeveloped in terms of service infrastructure. In 2018, the total number of companies serving the road freight transport of the Jambyl region comprised only $1 \%$ of all registered companies serving the road freight transport of Kazakhstan [68]. Consequently, the Jambyl region companies 
serving the road freight transport accounted for the smallest amount of income, equal to KZT 1.1 billion (US \$3361 million) in 2018 [68]. In the case of the Almaty region, transport companies preferred to be registered and operate from Almaty city [68].

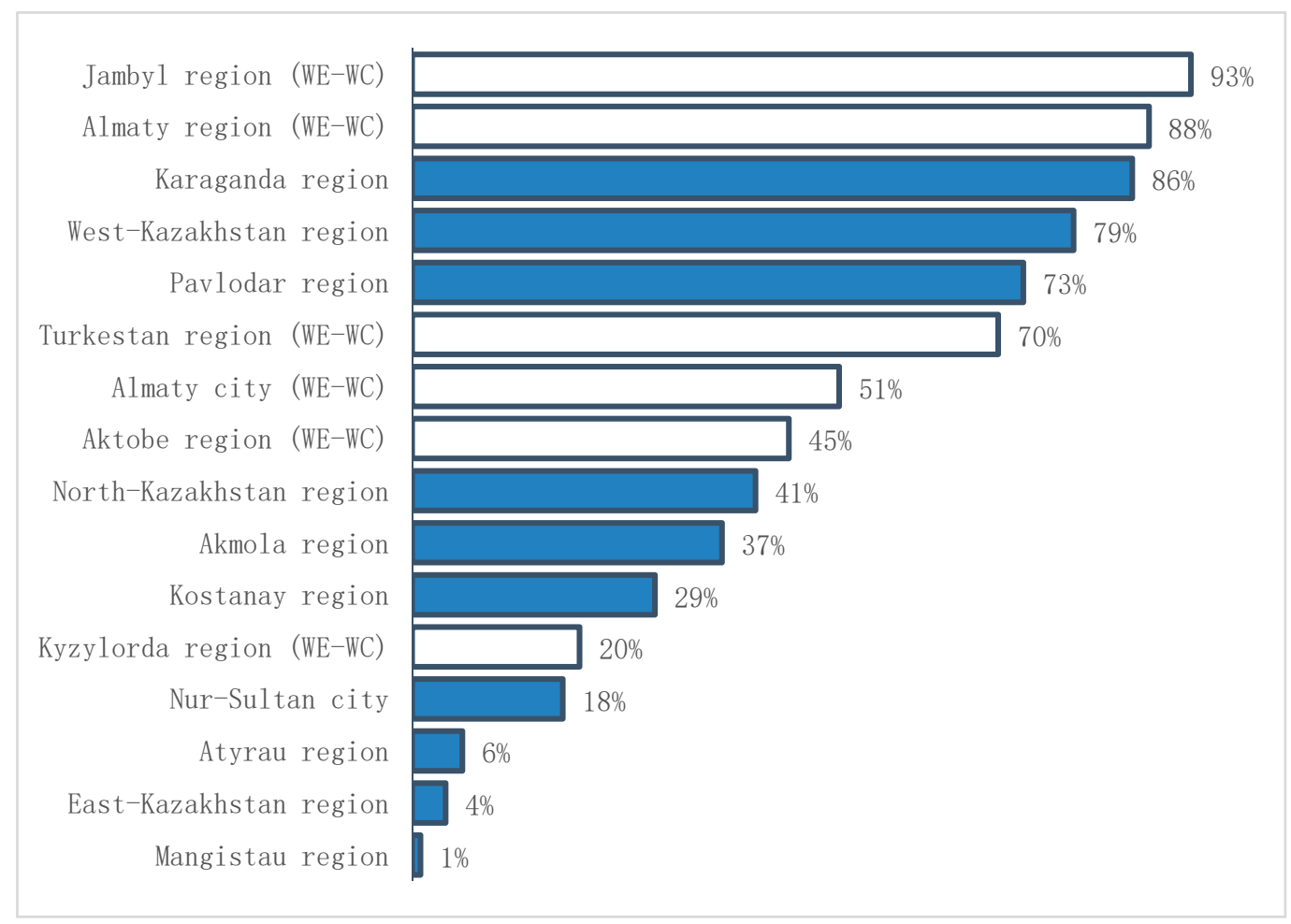

Figure 4. The share of exported non-commodity goods in total exports by regions in 2018 (based on statistics $[35,54]$ ).

Compared to Aktobe and Shymkent cities, Almaty city has the greatest potential to serve as a multimodal transport node for linking the WE-WC road with international air and railway corridors. Almaty city is a leader in the number of enterprises engaged in road freight transport and volume of revenue received from road freight transport. Compared to 2009, in 2019, among the WE-WC regions, the highest increase of the road freight turnover was recorded in Almaty city (4.4 times) [68]. In 2018, $20 \%$ of the country's companies engaged in road freight transport (1072 companies) were registered in Almaty city. Almaty city companies contributed 20.5\% (KZT 22 billion US $\$ 67,230$ million) of the total country revenue coming from the road freight transport-related services in 2018. Almaty city is home to $15 \%$ of the country's population, contributing more than $20 \%$ of the country's gross regional product (GRP) [54]. According to experts, the leadership of the city of Almaty in freight transport is associated with its distributional role as an international transport hub, where air and rail transport have developed equally [58]. Almaty city accounts for more than $50 \%$ of the country's air passenger and cargo traffic [57]. In 2018, 40,560 tons of cargo and 4380.2 thousand passengers were transported by Almaty's air transport [68]. The growth of export goods in Almaty's regions can also be explained by the other regions' ability to leverage their proximity to Almaty city. To the same extent, the Jambyl region could use its locational advantage, close to Bishkek, the largest city in neighboring Kyrgyzstan.

The transport corridor develops into the logistics corridor when there is a sustainable growth of road freight turnover. The evaluation showed that the government's expectations about the positive impact of the WE-WC corridor on the growth of trade volume and the export potential of regions were partially fulfilled. The timely completion of the Chinese section of the WE-WC corridor stimulated trade between China, Kazakhstan, and Kyrgyzstan. The Almaty and Jambyl regions, located close to Almaty city and Bishkek city, forming the China-Kyrgyzstan section of the WE-WC corridor, could increase the number of non-commodity export products. The Russian government could not 
complete its section of the WE-WC corridor in time. There was a low increase in trade between Russia and Uzbekistan. The mining regions of Aktobe, Kyzylorda, Turkestan, and Shymkent city, linking the Russia-Uzbekistan section of the WE-WC corridor, continued to be dependent on the export of commodity goods. As a result, this dependence undermines the sustainability of their economic future.

\subsection{The Change of Non-Commodity Export Products and the Diversification of the Regional Economy}

This section aims to assess the change in the development of regional capabilities to produce globally demanded non-commodity goods with high export value in regions along the WE-WC transport corridor. The assessment of regional capabilities showed that the regions bordering with China and Central Asian countries could increase the number of globally competitive products. During 2003-2014, the mining regions of Aktobe and Kyzylorda impacted by the global crisis experienced a decline in the processing sector. In 2014, the competitive advantage of the Aktobe and Kyzylorda regions was the lowest among the WE-WC regions (see Figure 5). In 2014, the mining sector accounted for $92.2 \%$ of the exports of the Kyzylorda region [40]. In 2014, the manufacturing sector of the Aktobe region contributed only 3\% of the country's total, and regional companies produced 19 types of globally competitive goods, including fuels, ferrous metals, chemicals, minerals, and food [40].

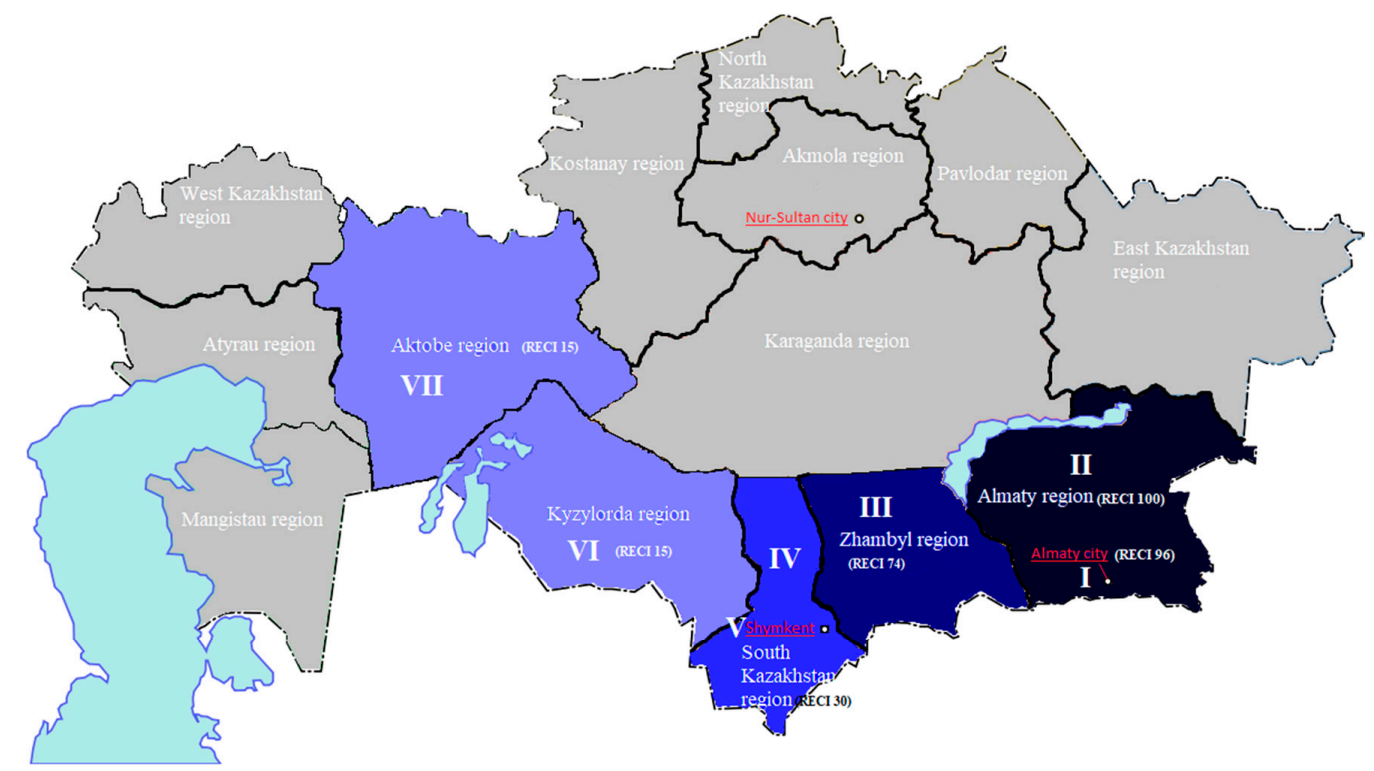

Regional Economic Complexity Index (RECI)

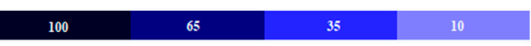

Figure 5. Regional Capability Index in 2014 by the WE-WC regions of Kazakhstan (adopted from Whiteshield Partners, 2015).

Among the WE-WC regions, the agricultural Jambyl and Almaty regions showed the highest increase in the number of globally competitive products. For example, during 2003-2014, the Jambyl region, neighboring Bishkek-the largest city of Kyrgyzstan, showed significant progress in capability development and a high level of economic diversification [40]. In 2014, the Jambyl region took the 3rd place among the WE-WC regions (see Figure 5). The average complexity of the products exported from the Jambyl region with RCA increased by $18 \%$, and the number of RCA rose from 62 to 106 , whereas new goods included leather and textile products as well as power-generating, industrial, and household machinery [40]. In 2014, only 3\% of the country's manufacturing sector was located in the Jambyl region, but these manufacturing companies produced 31 types of globally competitive 
goods in agriculture and food, 24 in leather, textile and apparel, 12 in stone glass and metal products, 11 in machinery products, and 5 in chemical products [40].

In 2012, the government of Kazakhstan introduced a regional development policy to develop the Almaty and Shymkent urban agglomerations via the stimulation of economic cooperation between four regions located along the WE-WC corridor: Almaty city, the Almaty region, Shymkent city, and the Turkestan region [72]. However, Almaty city and the Almaty region, compared to Shymkent city and the Turkestan region, showed a better engagement in a mutually beneficial exchange of goods and services and enjoyed benefits from the agglomeration effect. In 2014, Almaty city and the Almaty region, having the highest level of regional economic complexity and comparative advantage, were considered regions with high economic capability (see Figure 4). In 2014, Almaty city produced 276 types of globally competitive goods (RCA > 1), eight of which led the world ranking [40]. In 2014, the Almaty region was more diversified, with 165 RCAs, whereas the Turkestan region and Shymkent city had only 75 RCAs, including low-complexity products like fish, meat, and other agricultural goods [40]. The Turkestan region outperformed the Almaty region in terms of the size of processing sectors. However, the Almaty region produced more value-added goods, including $40 \%$ of exports coming from machinery and metals and 50\% of the export agricultural and food products [40]. In the case of the Turkestan region and Shymkent city, fuels and chemicals accounted for $65 \%$ and $15 \%$ of the exported goods [40].

The transport corridor develops into the economic corridor when it starts to stimulate territorial clustering of companies. In the case of the Almaty region, companies have started to create territorial clusters around Almaty city. The Almaty region has more opportunities to develop new products in the future and benefit from the operation of the WE-WC corridor. The Turkestan region and Shymkent city lost their comparative advantages in most sectors, with the highest decline in machinery, transport, stone, glass, and metal producing sectors. A minor positive change was observed in the Turkestan region and Shymkent city in chemical production, with new RCA products such as antibiotics, mineral or chemical fertilizers, and radioactive chemical elements. Also, the Turkestan region and Shymkent city slightly enhanced the production of the non-crude oil from petrol and bitumen minerals. However, the growing technological distance between the main producing sectors may not allow the Turkestan region and Shymkent city to benefit from the operation of the WE-WC corridor. The long-term economic sustainability of the WE-WC linking regions depends on local conditions created for companies to produce non-commodity products with high export value. There is an urgent need to develop capacities of regional governments to enhance the development and maintenance of transport infrastructure, as well as to create better institutional conditions to increase the competitive advantages of the locally produced goods and services [65].

\section{Conclusions}

This study fills the gap in the literature on the impact of the Silk Road transport corridors on regional development in Central Asia. The authors proposed an original methodological framework for assessing the impact of the transport corridor, considering its evolution from a transport into an economic corridor. The proposed methodological framework was based on the integrated approach. It tracked the change by illustrating how the transport sustainability was related to sustainable logistics and sustainable regional economic development in Central Asia.

The study's findings allowed us to divide the WE-WC transport corridor into two main sections, according to the evolution level and followed-up impact: (i) the road section linking Russia and Uzbekistan via Kazakhstan, passing through the Aktobe, Kyzylorda, and Turkestan regions and Shymkent city (the Russia-Uzbekistan section); and (ii) the road section linking China and Kyrgyzstan via Kazakhstan, passing through Almaty city, the Almaty region and the Jambyl region (the China-Kyrgyzstan section). The WE-WC Russia-Uzbekistan section continues to serve mainly a transit function and operate at the level of transport infrastructure. The WE-WC China-Kyrgyzstan 
section has started to evolve from the level of the multimode transport corridor to the level of the logistics corridor.

Unfortunately, as the evidence has shown, the rehabilitation of the WE-WC road did not lead to the expected improvement of roads in all regions. The number of road accidents decreased in regions located along the Russia-Uzbekistan section of the WE-WC corridor, but this was linked with the decrease in the traffic flow due to the low quality of the road surface. If the government of Kazakhstan wants to help road users to save on traveling time and the repairment of vehicles, it is important to increase the quality of roads by improving road construction and maintenance. Mining regions forming the Russia-Uzbekistan section of the WE-WC corridor showed higher sensitivity to the negative impact of the global crisis. This means that the sustainability of the Aktobe, Kyzylorda, and Turkestan regions and Shymkent city depends on their economic diversification. If the government of Kazakhstan wants to raise the WE-WC Russia-Uzbekistan section to the level of a multimode transport corridor, it is vital to support regional governments by effective public investments in the improvement of regional transport systems.

Despite the negative impact of the global economic recession on international trade including the exchange of goods between China and Europe, there was the highest increase in trade volume between China and Kyrgyzstan. The increase stimulated the economic diversification of the WE-WC linking the Almaty and Jambyl regions. The Almaty and Jambyl regions, located close to Almaty city and Bishkek, showed good performance by increasing a variety of value-added export products and the geographic clustering of producers along to the WE-WC road. Almaty city and the Almaty region became closely interconnected by the existing transport and storage infrastructure. The large number of transport companies located in the periphery of Almaty city, as well as the warehouse of the Almaty region, have started to concentrate around Almaty city. If the government of Kazakhstan aims to raise the WE-WC China-Kyrgyzstan section to the level of an economic corridor, it must develop the capacity of regional managers to create an enabling business environment that stimulates the development of regional capabilities and the related logistics infrastructure.

The Kazakhstan section of the WE-WC corridor is at an early stage of the transformation from a transport into a logistics corridor. Therefore, the impact of the WE-WC corridor requires more attention and further research funded by the government. The analysis of assumed impacts should not be limited to the assessment of savings, overall change of the freight turnover, or received profit from the trade. It is important to measure the change in economic complexity of regions driven by the development of transport infrastructure. The economic sustainability of the WE-WC route linking cities and regions depends on what would be done for the successful evolution of the transport corridor into the logistics corridor. To make future BRI-related investments beneficial to sustainable economic development, Central Asian governments should accompany the infrastructure development investment with region-specific actions enabling economic diversification.

There are several limitations of the study worth mentioning. This paper presents only findings of the regional-level analysis. The study of behavioral aspects of key actors engaged in the development of logistics chains in cities and regions of Kazakhstan, based on the mathematical models suggested by leading scholars [20], will be completed in 2021 and published in a different paper. The study was funded by a governmental grant. Therefore, the research design was constrained by the grant-suggested research scope and objectives and required the authors to focus on cities and regions of Kazakhstan. Constrained by the study objective and the shortage of data, the authors did not assess the impact of WE-WC on Russian and Chinese regions, nor did they compare the officially approved WE-WC route with other possible alternative routes. However, there is a plan to continue research on the impact of the Silk Road corridors on Central Asian countries as well as Russia, China, Belarus, and Eastern European countries such as Poland. The research makes a modest step toward the development of an evidence-based decision-making culture in the policymaking of Kazakhstan. The paper paves the way for further in-depth research on the role of transport and logistics for sustainable economic development in regions of Central Asia. 
Author Contributions: Data curation, A.T. and M.J.; formal analysis, A.T. and M.J.; funding acquisition, G.L.; investigation, G.L.; methodology, G.L. and M.J.; software, A.T. and M.J.; validation, G.L. and M.J.; visualization, A.T.; writing—original draft, A.T. and M.J.; writing—review \& editing, G.L. and M.J. All authors have read and agreed to the published version of the manuscript.

Funding: This study was funded by the Science Committee of the Ministry of Education and Science of the Republic of Kazakhstan BR05236340 "Creation of high-performance intelligent analysis and decision-making technologies for the 'logistics-agglomeration' system within the formation of the Republic of Kazakhstan's digital economics".

Conflicts of Interest: The authors declare no conflicts of interest.

\section{References}

1. Asian Development Bank. CAREC Transport and Trade Facilitation Strategy 2020; Asian Development Bank: Mandaluyong, PA, USA, 2014; Volume 73, pp. 20-22.

2. Western Europe-Western China Transit Corridor Economic and Social Effects of the Project|Западная Европа-Западный КитайМеждународныйТранзитный коридор. Available online: https:/europe-china. kz/en (accessed on 13 June 2020).

3. Western Europe-Western China Transit Corridor The Map of the Project, Slides, Schemes, Models|Западная Европа-Западный КитайМеждународныйТранзитный коридор. Available online: http://europe-china. kz/en/links (accessed on 13 June 2020).

4. Czerewacz-Filipowicz, K. The Eurasian Economic Union as an Element of the Belt and Road Initiative. Comp. Econ. Res. 2019, 22, 23-37. [CrossRef]

5. Lobyrev, V.; Tikhomirov, A.; Tsukarev, T.; Vinokurov, E. Belt and Road Transport Corridors: Barriers and Investments; No. Report 50; Eurasian Development Bank Centre for Integration Studies' Reports: Saint Peterburg, Russia, 2018; pp. 8-11.

6. Wang, Y. Full text of President Xi Jinping Speech at the Opening of Belt and Road Forum. Xinhua. 2017. Available online: http://www.xinhuanet.com//english/2017-05/14/c_136282982.htm (accessed on 13 June 2020).

7. Ma, D.; Lei, C.; Ullah, F.; Ullah, R.; Baloch, Q.B. China's One Belt and One Road Initiative and Outward Chinese Foreign Direct Investment in Europe. Sustainability 2019, 11, 7055. [CrossRef]

8. Pei, M. Chinas Expensive Bet on Africa Has Failed-Nikkei Asian Review. Nikkei Asian Review. 2020. Available online: https://asia.nikkei.com/Opinion/China-s-expensive-bet-on-Africa-has-failed (accessed on 13 June 2020).

9. Shukry, A.; Park, K. Malaysia Scraps Multibillion-Dollar High-Speed Rail Project to Singapore. Bloomberg. 2018. Available online: https://www.bloomberg.com/news/articles/2018-05-28/mahathir-to-scrap-malaysiasingapore-high-speed-rail-project (accessed on 13 June 2020).

10. Ohashi, H. The Belt and Road Initiative (BRI) in the context of China's opening-up policy. J. Contemp. East Asia Stud. 2018, 7, 85-103. [CrossRef]

11. Jaborov, S. Chinese Loans in Central Asia: Development Assistance or "Predatory Lending" . In China's Belt Road Initiative and Its Impact in Central Asia; Laruelle, M., Ed.; The George Washington University, Central Asia Program: Washington, DC, USA, 2018; pp. 34-40, ISBN 978-0-9996214-0-0.

12. Voon, J.P.; Xu, X. Impact of the Belt and Road Initiative on China's soft power: Preliminary evidence. Asia-Pac. J. Account. Econ. 2020, 27, 120-131. [CrossRef]

13. Dellios, R.; Ferguson, R.J. The Human Security Dimension of China's Belt and Road Initiative. J. Manag. Sustain. 2017, 7, 48. [CrossRef]

14. Teo, H.C.; Lechner, A.M.; Walton, G.W.; Chan, F.K.S.; Cheshmehzangi, A.; Tan-Mullins, M.; Chan, H.K.; Sternberg, T.; Campos-Arceiz, A. Environmental impacts of infrastructure development under the belt and road initiative. Environment 2019, 6, 72. [CrossRef]

15. Ascensão, F.; Fahrig, L.; Clevenger, A.P.; Corlett, R.T.; Jaeger, J.A.G.; Laurance, W.F.; Pereira, H.M. Environmental challenges for the Belt and Road Initiative. Nat. Sustain. 2018, 1, 206-209. [CrossRef]

16. Tracy, E.F.; Shvarts, E.; Simonov, E.; Babenko, M. China's new Eurasian ambitions: The environmental risks of the Silk Road Economic Belt. Eurasian Geogr. Econ. 2017, 58, 56-88. [CrossRef]

17. Khan, M.K.; Sandano, I.A.; Pratt, C.B.; Farid, T. China's Belt and Road Initiative: A global model for an evolving approach to sustainable regional development. Sustainability 2018, 10, 4234. [CrossRef] 
18. Liu, J. Development of Regional Logistics in the Belt and Road. In Current Chinese Economic Report Series; Springer: Singapore, 2018; pp. 205-221. [CrossRef]

19. Goswami, M.; De, A.; Habibi, M.K.K.; Daultani, Y. Examining freight performance of third-party logistics providers within the automotive industry in India: An environmental sustainability perspective. Int. J. Prod. Res. 2020. [CrossRef]

20. De, A.; Mogale, D.G.; Zhang, M.; Pratap, S.; Kumar, S.K.; Huang, G.Q. Multi-period multi-echelon inventory transportation problem considering stakeholders behavioural tendencies. Int. J. Prod. Econ. 2020, 225. [CrossRef]

21. Öberg, M.; Nilsson, K.L.; Johansson, C. Major transport corridors: The concept of sustainability in EU documents. Transp. Res. Procedia 2017, 25, 3694-3702. [CrossRef]

22. Standish, R. China's Belt and Road Initiative Is Running Into Problems. The Atlantic. 2019. Available online: https://www.theatlantic.com/international/archive/2019/10/china-belt-road-initiativeproblems-kazakhstan/597853/ (accessed on 13 June 2020).

23. Lu, H.; Rohr, C.; Hafner, M.; Knack, A. China Belt and Road Initiative: Measuring the impact of improving transportation connectivity on trade in the region. China Belt Road Initiat. Meas. Impact Improv. Transp. Connect. Trade Reg. 2018. [CrossRef]

24. Lakshmanan, T.R. The broader economic consequences of transport infrastructure investments. J. Transp. Geogr. 2011, 19, 1-12. [CrossRef]

25. Sun, J.; Li, Z.; Lei, J.; Teng, D.; Li, S. Study on the Relationship between Land Transport and Economic Growth in Xinjiang. Sustainability 2018, 10, 135. [CrossRef]

26. Energy and Engineering: What China Invests in Almaty Region/Энергетика и машиностроение: во что инвестирует Китай вАлматинскойобласти. Available online: http://today.kz/news/ekonomika/2017-10-03/ 751481-energetika-i-mashinostroenie-vo-chto-investiruet-kitaj-v-almatinskoj-oblasti/ (accessed on 13 June 2020).

27. The World Bank Belt and Road Economics: Opportunities and Risks of Transport Corridors. Belt Road Econ. Oppor. Risks Transp. Corridors 2019. [CrossRef]

28. Roberts, M.; Melecky, M.; Bougna, T.; Xu, Y. (Sarah) Transport Corridors and Their Wider Economic Benefits: A Critical Review of the Literature; Policy Research Working Paper No. 8302; The World Bank: Washington, DC, USA, 2018; pp. 207-248. [CrossRef]

29. Li, P.; Cao, X.S. Evolution and development of Guangzhou-Hong Kong corridor. Chin. Geogr. Sci. 2005, 15, 206-211. [CrossRef]

30. White, H. Achieving high-quality impact evaluation design through mixed methods: The case of infrastructure. J. Dev. Eff. 2011, 3, 131-144. [CrossRef]

31. YILDIRIR KESER, H. Importance of Transport Corridors in Regional Development: The Case of TRACECA. Sosyoekonomi 2015, 24. [CrossRef]

32. Hope, A.; Cox, J. Economic and Private Sector Professional Evidence and Applied Knowledge Services. Available online: https://assets.publishing.service.gov.uk/media/57a08995e5274a31e000016a/Topic_Guide_ Development_Corridors.pdf (accessed on 13 June 2020).

33. Li, Y.; Schmerer, H.J. Trade and the New Silk Road: Opportunities, challenges, and solutions. J. Chin. Econ. Bus. Stud. 2017, 15, 205-213. [CrossRef]

34. Şeker, A.; Şimdi, H. The Relationship Between Economic Complexity Index and Export: The Case of Turkey and Central Asian and Turkic Republics. Econ. Reg. 2019, 15, 659-669. [CrossRef]

35. State Revenue Committee Ministry of finance of the Republic of Kazakhstan. Available online: http: //kgd.gov.kz/en (accessed on 13 June 2020).

36. The Statistics Committee of the Ministry of National Economy of the Republic of Kazakhstan Home Page. Available online: https://stat.gov.kz/ (accessed on 6 November 2019).

37. Exports of Goods and Services (Current US\$)|Data. Available online: https:/data.worldbank.org/indicator/ NE.EXP.GNFS.CD (accessed on 7 May 2020).

38. Research Report by NIITK Within the Participation in the International Transport Run on Gas Engine Fuel on the Europe-China Transport Route. Available online: http://kazlogistics.kz/upload/iblock/954/ 9547a1c5a43e8866081292dfebb94db2.pdf (accessed on 13 June 2020).

39. Hillman, J.E. Safety on the New Silk Road: Assessing Kazakhstan's Highways; Center for Strategic and International Studies: Washington, DC, USA, 2017; p. 20036. 
40. Farra, F.; Sigalova, O.; Dmitrieva, Y.; Klos, N.; Ospanova, D. Diversification of Kazakhstan's Economy: A Capability-Based Approach; Technical Report for EBRD and the Government of the Republic of Kazakhstan: Whiteshield Partners, Astana, September 2015.

41. The Atlas of Economic Complexity. Available online: https://atlas.cid.harvard.edu/ (accessed on 9 March 2020).

42. Aislu, T.; Bagdat, T.; Loprencipe, G.; Nailya, I. Analysis of enterrelation between economic, road, transport and logistic indicators. News Natl. Acad. Sci. Repub. Kazakhstan Ser. Geol. Tech. Sci. 2020, 2, 162-169. [CrossRef]

43. Message From the President of the Republic of Kazakhstan N. Nazarbayev to the People of Kazakhstan. 6 February 2008-Послание Президента Республики Казахстан Н.Назарбаева народу Казахстана. 6 февраля2008 г.-Официальный сайтПрезидента Республики Казах. Available online: http://www.akorda.kz/ru/addresses/addresses_of_president/poslanie-prezidenta-respubliki-kazahstannnazarbaeva-narodu-kazahstana-6-fevralya-2008-g (accessed on 13 June 2020).

44. 10 Years since Signing the Agreement on Establishing the "Western Europe-Western China" Corridor-10 лет исполнилось подписанию документа о создании коридора «Западная Европа-Западный Китай». Available online: https://www.inform.kz/ru/10-let-ispolnilos-podpisaniyu-dokumenta-o-sozdanii-koridorazapadnaya-evropa-zapadnyy-kitay_a3517678 (accessed on 13 June 2020).

45. Movkebaeva, G.A. Energy cooperation among Kazakhstan, Russia, and China within the Shanghai cooperation organization. Russ. Polit. Law 2013, 51, 80-87. [CrossRef]

46. Cooperation Plan for Pairing the 'Nurly Zhol' and 'New Economic Policy and the Construction of the Silk Road Economic Belt' between the Government of the Republic of Kazakhstan and the Government of the People's Republic of China-O подписанииПлана сотр. Available online: https://tengrinews.kz/zakon/pravitelstvo_respubliki_kazahstan_premer_ministr_rk/mejdunapodnyie_ otnosheniya_respubliki_kazahstan/id-P1600000518/ (accessed on 13 June 2020).

47. Taldybayeva, D. Western China-Western Europe Corridor: Problems and Solutions. Eurasian Research Institute Weekly E-bulletin No. 206. 2019. Available online: https:/eurasian-research.org/web/publications/ Weekly-e-bulletin-08-04-2019-14-04-2019-No-206.pdf?1557305885 (accessed on 13 June 2020).

48. Fursova, I. The Transit Is Not Manageable / Строительство трассы“Западная Европа-Западный Китай” затягивается-Российская газета. Available online: https://rg.ru/2014/08/19/magistral.html (accessed on 13 June 2020).

49. On the Approval of the Plan of the Modernization and Expansion of the Highway Infrastructure till 2024|Об утверждении Комплексного плана модернизации ирасширения магистральной инфраструктуры на период до 2024 года. Available online: http://government.ru/docs/34297/ (accessed on 13 June 2020).

50. Bonin, G.; Polizzotti, S.; Loprencipe, G.; Folino, N.; Oliviero Rossi, C.; Teltayev, B.B. Development of a road asset management system in kazakhstan. In Transport Infrastructure and Systems-Proceedings of the AIIT International Congress on Transport Infrastructure and Systems, TIS 2017; CRC Press/Balkema: Leiden, The Netherlands, 2017; pp. 537-545, ISBN 9781138030091.

51. Public Signing of the Decree 'On Some Issues of the Administrative-territorial Structure of the Republic of Kazakhstan|Публичное подписание Указа «О некоторых вопросахадминистративно-территориального устройства Республики Казахстан»-Официальный сайт. Available online: http://www.akorda. kz/ru/events/akorda_news/akorda_other_events/publichnoe-podpisanie-ukaza-o-nekotoryh-voprosahadministrativno-territorialnogo-ustroistva-respubliki-kazahstan (accessed on 13 June 2020).

52. Kazakhstan's Export and Import: What, How Much and Where the Country Sells and Вuys|Казахстанский экспорт и импорт: что, сколько и куда продаёт и покупает страна-Forbes Kazakhstan. Available online: https://forbes.kz/finances/finance/eksport_kto_ostaetsya_klyuchevyim_pokupatelem_ kazahstanskoy_nefti/ (accessed on 13 June 2020).

53. Official Website of the Ministry of Finance of the Republic of Kazakhstan. Available online: http://kgd.gov. kz/en (accessed on 13 June 2020).

54. The Statistics Committeee of the Ministry of National Economy Republic of Kazakhstan Statistics by Regions. Available online: https://stat.gov.kz/region/268020/statistical_information/industry (accessed on 13 June 2020).

55. Kazakhstan, T.S.C. of the M. of N.E.R. of Foreign And Mutual Trade Statistics. Available online: https: //stat.gov.kz/official/industry/31/statistic/6 (accessed on 13 June 2020).

56. Di Mascio, P.; Loprencipe, G.; Moretti, L. Competition in rail transport: Methodology to evaluate economic impact of new trains on track. In Proceedings of the Sustainability, Eco-Efficiency and Conservation in Transportation Infrastructure Asset Management, ICTI 2014, Pisa, Italy, 22-25 April 2014; pp. 669-675. 
57. Damu Eterpreneurship Development Fund. Establishing the Logistics Center. Business Plan; Indigo Print: Almaty, Kazakhstan, 2012.

58. Damu Logistics Leader of the Logistics in Kazakhstan. DL News Corp. J. 2017, 1, 4-9.

59. East-West Roads Project (Almaty-Korgos Section): Western Europe-Western China International Transit Corridor (CAREC—1b). Available online: https://projects.worldbank.org/en/projects-operations/projectdetail/P128050 (accessed on 13 June 2020).

60. On the State Programme of Development and Support of the Small Business in Kazakhstan for 2004-2006. Available online: https://tengrinews.kz/zakon/prezident_respubliki_kazahstan/hozyaystvennaya_deyatelnost/ id-U030001268_/ (accessed on 13 June 2020).

61. On Approval of the Programme "Road Map of Business Development 2020"|Об утвержденииПрограммы“Дорожная карта бизнеса 2020”. Available online: https://zakon.uchet. kz/rus/docs/P100000301_ (accessed on 13 June 2020).

62. Saiymova, M.; Yesbergen, R.; Demeuova, G.; Bolatova, B.; Taskarina, B.; Ibrasheva, A.; Spankulova, L.; Saparaliyev, D. The knowledge-based economy and innovation policy in Kazakhstan: Looking at key practical problems. Acad. Strateg. Manag. J. 2018, 17, 1-11.

63. On Approval of the Program of Transport Infrastructure Development in the Republic of Kazakhstan. Available online: http://www.kazcargo.kz/en/o_kompanii/zakonodatel_stvo/o_transportnoj_strategii_ respubliki_kazahstan_do_2015_goda/ (accessed on 13 June 2020).

64. Order of the Government of the Republic of Kazakhstan About approval of the National Export Strategy Program. Available online: https://cis-legislation.com/document.fwx?rgn=100222 (accessed on 13 June 2020).

65. Junussova, M. Cities and Local Governments in Central Asia; Routledge, Ed.: Abingdon-on-Thames, UK, 2020; ISBN 9780367279196.

66. Autotourist kz about Roads and Travel|Автотурист кзо дорогах и путешествиях. Available online: http://autotourist.kz/index.php/routes (accessed on 21 July 2020).

67. Pantuso, A.; Loprencipe, G.; Bonin, G.; Teltayev, B.B. Analysis of pavement condition survey data for effective implementation of a network level pavement management program for Kazakhstan. Sustainability 2019, 11, 901. [CrossRef]

68. Kazakhstan, S.C. of the M. of N.E.R. of Cargo Transport and Cargo Services. Available online: https: //stat.gov.kz/official/industry/18/statistic/7 (accessed on 13 June 2020).

69. Demasi, F.; Loprencipe, G.; Moretti, L. Road safety analysis of urban roads. Case study of an Italian municipality. SAFETY 2018, 4, 58. [CrossRef]

70. In 2020, Kazakhstan will Begin the Implementation of the European Road Condition Assessment System [В 2020 году в Казахстане начнется внедрение европейской системыоценки состояния дорог]. Available online: https://www.inform.kz/ru/v-2020-godu-v-kazahstane-nachnetsya-vnedrenie-evropeyskoysistemy-ocenki-sostoyaniya-dorog_a3602372 (accessed on 21 July 2020).

71. World Integrated Trade Solution China|Capital goods|Exports and Imports|by all Countries|2018|WITS|Data. Available online: https://wits.worldbank.org/CountryProfile/en/Country/CHN/Year/2018/TradeFlow/ EXPIMP/Partner/all/Product/UNCTAD-SoP4 (accessed on 13 June 2020).

72. On Approval of “The Regional Development” Program|Об утвержденииПрограммы“Развитие регионов"-ИПС “Әділет”. Available online: http://adilet.zan.kz/rus/docs/P1100000862 (accessed on 13 June 2020).

(C) 2020 by the authors. Licensee MDPI, Basel, Switzerland. This article is an open access article distributed under the terms and conditions of the Creative Commons Attribution (CC BY) license (http://creativecommons.org/licenses/by/4.0/). 